April 2010

\title{
From Real Friend to Imagined Foe: The Medieval Roots of Anti- Semitism as a Precondition for the Holocaust
}

Christopher Tuckwood

\section{Recommended Citation}

Tuckwood, Christopher (2010) "From Real Friend to Imagined Foe: The Medieval Roots of Anti-Semitism as a Precondition for the Holocaust," Genocide Studies and Prevention: An International Journal: Vol. 5: Iss. 1: Article 6.

Available at: https://digitalcommons.usf.edu/gsp/vol5/iss1/6

This Articles is brought to you for free and open access by the Open Access Journals at Digital Commons @ University of South Florida. It has been accepted for inclusion in Genocide Studies and Prevention: An International Journal by an authorized editor of Digital Commons @ University of South Florida. For more information, please contact digitalcommons@usf.edu. 


\title{
From Real Friend to Imagined Foe: The Medieval Roots of Anti-Semitism as a Precondition for the Holocaust
}

\author{
Christopher Tuckwood \\ Sentinel Project for Genocide Prevention, Toronto, ON
}

This study examines the medieval roots of European anti-Semitism as a precondition for the Holocaust. The twelfth century saw an important transition from Jews being viewed as the adherents of a competing religion to dangerous, inhuman threats to the broader Christian society for the first time. Northern France is used as a case study, examining several Jewish, Christian, and secular primary sources to understand the factors leading to gradual Jewish dehumanization. Growing Church influence and resulting restrictions forced some Jews into what would become their stereotypical occupation of moneylending. Lacking awareness of this broader process and as a result of Church propaganda, the Christian majority came to see Jews as a threat associated with foreign and supernatural enemies. Ultimately, both the people and rulers found the victimization of Jews desirable, culminating in the burning of the Jews of Blois and their expulsion from the French Royal Domains. These results help to explain the beginning of a centuries-long process which had already dehumanized Jews by the time that the Nazis redefined and racialized anti-Semitism in the early twentieth century.

Key words: anti-Semitism, Holocaust, medieval, Europe, preconditions

\section{Introduction}

It is often taken for granted in Holocaust studies that general European anti-Semitism was a convenient, and probably necessary, precondition for the Nazi assault upon European Jewry. Without this existing atmosphere of, at best, indifference and, at worst, violent hostility toward Jews throughout Europe, the Nazis would not have found such apathetic bystanders and enthusiastic collaborators during their campaign of extermination. This anti-Semitism did not always exist in Europe but its roots are rarely discussed, even though they extend back a millennium into the early medieval period when fundamental popular attitudes toward Jews underwent a major shift due to the interaction of social, economic, and religious factors. This very important change meant that Christian Europeans no longer saw Jews only as the misguided adherents of an outdated religion, but rather as innately threatening beings who could be subjugated, abused, and even eliminated en masse.

The purpose of this article is to shed some light upon these roots within the context of the larger genocidal process. This is not to say that the development of medieval anti-Semitism was intentional or part of a deliberate dehumanization process, or even that it was responsible in any way for the Holocaust. Rather, it is to say that this type of Jew-hatred did not always exist and that its origins must be considered in order to understand how the stage was set for successive pogroms and expulsions over the centuries and ultimately contributed as an enabling factor in

Christopher Tuckwood, "From Real Friend to Imagined Foe: The Medieval Roots of AntiSemitism as a Precondition for the Holocaust." Genocide Studies and Prevention 5, 1 (April 2010): 89-105. (C) 2010 Genocide Studies and Prevention. doi:10.3138/gsp.5.1.89 
the Holocaust of the twentieth century. Understanding the medieval origins of antiSemitism will ultimately contribute to a greater understanding of the preconditions for the Holocaust. These origins are complex and involve various religious, economic, political, and social factors that could each inspire much larger studies. However, as much detail as possible will be given in the space available, as well as a small case study focusing on northern France. While this study is in no way intended to provide a simple monocausal explanation of anti-Semitism, particular attention will be paid to the changing Jewish socioeconomic role and its interaction with Church teachings about Jews during the eleventh and twelfth centuries, which appear as the most salient factors of that period, and gave rise to the most enduring anti-Semitic myths.

Anti-Jewish hostility is a constantly evolving force which has taken various forms both today and in the past, even though its most commonly used label, antiSemitism, has only existed in modern times ${ }^{1}$ and only refers to a phenomenon about nine centuries old. Just as the emergence of racially based anti-Semitism during the early twentieth century was a major development in Jew-hatred, so too was the initial emergence of anti-Semitism during the eleventh century. Prior to that period, anti-Jewish hostility was religiously motivated and almost exclusively clerical, without any known associated violence. Because of its almost exclusively religious nature, scholars call this form anti-Judaism. However, between the ninth and twelfth centuries there was a gradual shift to often violent, popular, and political hostility: essentially, anti-Semitism. Medieval anti-Semitism was a precursor to the modern phenomenon of the same name and was characterized by an irrational fear and hatred of Jews as threatening subhumans that Gavin Langmuir has defined as "the hostility aroused by irrational thinking about 'Jews",2 as the "Other." By the late twelfth century, Jews were no longer protected subjects and social equals with whom one might disagree theologically, but a violently persecuted and marginalized minority. Although medieval Jews generally carried on peaceful lives and avoided the constant victimization that is sometimes associated with them, their history from the twelfth century on was punctuated and characterized by increasingly violent attacks.

To clarify, anti-Judaism is a semi-rational opposition to Judaism as a religion and Jews as its adherents based on theological judgments. This form found itself quite popular in clerical circles at all levels of the Roman Catholic Church, but failed to gain many, if any, adherents among the laity. It is perhaps characterized best as a "normal, albeit lamentable interreligious rivalry"3 caused by a perceived Jewish threat to Christianity. Differing from anti-Judaism is anti-Semitism, the irrational fear and hatred of Jews because they are perceived to be innately harmful and dangerous beings, both spiritually and physically. ${ }^{4}$ Anti-Semitism developed out of antiJudaism but far surpassed the intent or control of the clergy and became popular among laypeople and rulers who developed quasi-religious, counterfactual beliefs about Jews.

Most scholars explain the transition from anti-Judaism to anti-Semitism exclusively in religious, economic, or social terms, with little effort to harmonize the three. In actual fact, the inter-relationship of these three areas cannot be ignored, because people do not operate in each of these roles separately but rather live a unified life. Essentially, religiously inspired economic and legal changes throughout the ninth, tenth, and eleventh centuries marginalized Jews in society and created an atmosphere in which existing religious ideas about them were popularly received and gradually became exaggerated to the point of occasional and extreme violence by the end of the twelfth century. During this period, an important political transition 
also took place when the Carolingian Empire dissolved and the Capetian monarchs rose to power and began to shape what would become the kingdom of France. The experiences of Jews across Europe, though certainly sharing many common elements, were diverse at this time, and so it will be necessary to concentrate on a specific political region in order to coherently track the development of anti-Semitism. The northern area of modern France surrounding Paris will be ideal for this, as it was a prominent area in the landscape of the western Carolingian Empire, and then the Royal Domains under the direct control of the Capetians. The events that occurred there represented a pattern and process in the development of antiSemitism common to other areas, though regional nuances were significant. As a result, the case examined is useful, but caution must be exercised not to overgeneralize the conclusions drawn from this evidence and their implications for broader European anti-Semitism leading up to the Holocaust. Unfortunately, both primary and academic sources on the Jewish experience in this place and time are scant, so it will sometimes be necessary to deal with information of a more general nature, from neighboring regions, or from different times in order to extrapolate meaning for the places and events in question.

\section{Jews in the Carolingian Empire: Tolerance and Integration}

The Jews of early medieval Gaul living under the Frankish Merovingian dynasty could hardly have been further from the wretched state that their descendants would find themselves in five centuries later. They formed a secure and influential minority, with many friends and supporters at court and important economic, social, and political roles to play themselves, which guaranteed that they enjoyed a comfortable place in society. ${ }^{5}$ From the early seventh century onward, the Merovingian kings began to decline in power until they were mere figureheads and their mayors of the palace ruled instead. One such mayor, Charles "the Hammer" Martel, actually ruled for several years without a king, but upon his death his sons Carloman and Pippin attempted to stem rebellion by appointing the man who would be the last Merovingian, Childeric III, in $743 .{ }^{6}$ Carloman withdrew from public life in 747 , taking the tonsure and retiring to a monastery near Rome. ${ }^{7}$ With all competition thus removed, Pippin had himself elected King of the Franks in 751 and deposed Childeric III, thus ending the Merovingian dynasty of "do-nothing kings," replacing it with Carolingian rule. ${ }^{8}$

It is not clear what, if any, role that Jews played during the transition to Carolingian rule, but they were by no means a community of singular mind or action, and likely held varying positions depending upon their circumstances. Pippin made his Jewish policy clear only after 768, when he conquered Aquitaine and affirmed the personality of the law $^{9}$ for Jews so that they could continue to live under their own laws and still enjoy the privileges previously given to them. ${ }^{10}$ It is clear from the sources that Carolingian Jews enjoyed a social status nearly, if not fully, equal to that of their Christian neighbors. One has to remember that the Carolingian Empire was an eclectic organization, and that Jews were just one of many small ethnic groups. Aside from their unique religion in a predominantly Christian society, little would have set the Jews apart, since they had the same occupations, wore the same clothes, spoke the same language, and enjoyed much of the same culture as their neighbors. Perhaps the greatest testament to the highly integrated social status of the Jews at the time was the writings of clerics and the efforts of the Church in general, urging segregation of Jews from Christians. In a letter to Louis the Pious about 826, Archbishop Agobard of Lyon urged for the separation of Jews and Christians, citing a long list of accusations, among them that "[the Jews] lie to simple Christians 
and boast that they are dear to you [Louis] ... most excellent people desire [the Jews'] prayers and blessings ..." and "naïve Christians say that the Jews preach to them better than our priests." 11 Even leaving room for a preacher's hyperbole, one gets a real sense of fear from Agobard's writings. Certainly the Church would not have reacted so strongly to something that was not happening at all, and two of its main goals were to prevent Jewish-Christian intermarriage and conversions to Judaism. Other sources confirm that it was common at the time for Christians and Jews to dine together on kosher food, discuss religious ideas, and for Christians to adopt Jewish customs such as resting on Saturday and celebrating Jewish holidays while neglecting their own. Such practices likely even extended to the imperial court, and clerical alarm is thus not surprising. ${ }^{12}$

The Carolingians treated Jews as "Romans" and so they lived under Roman law in public matters but also had the privilege of being subject to Jewish law and courts in private matters internal to the Jewish community. The Byzantine Justinian's Code and the earlier Roman Theodosian Code were the two bodies of law used as a foundation for Jewish legislation in Carolingian Europe. Although both documents placed restrictions upon Jews, the Theodosian Code was by far the more lenient of the two and so it was the one most often enforced. Even some popes, such as Gregory I, seem to have preferred it. The laws of Theodosius were also more ambiguous in their declarations and so secular rulers were able to bend the rules in favor of Jews-whether the Church agreed to this practice or not-while still technically adhering to the letter of the law. A ruler's successors also often simply ignored or even overturned secular laws passed against the Jews. Most notably, rulers, in defiance of even the most permissive laws, often gave Jews high appointments in government and allowed them to own Christian slaves despite their prohibition from having authority over Christians. ${ }^{13}$

In addition to receiving near-equal treatment with their Christian neighbors, Carolingian Jews often enjoyed privileges unique to them. Jewish merchants frequently received exemptions from tolls and taxes, received official protection from the office of the magister Iudeorum and, most gallingly to Agobard of Lyon, had market days officially moved to Sunday so that the Jewish Sabbath would not be violated by business. ${ }^{14}$ In fact, the privileges granted to private Jewish merchants were at least as good as those given to non-Jewish traders in the service of the king. ${ }^{15}$ All of these special concessions to Jewish merchants indicate, without a doubt, that their economic importance must have been disproportionate to their small numbers. Jews were, in fact, the primary traders of (largely Christian) slaves captured during Charlemagne's campaigns ${ }^{16}$ and their great mobility, higher education, and connections across Europe and to the East meant that Jews were very useful to the king for foreign trade. ${ }^{17}$

Of course, as would be the case with moneylenders later on, merchants during the Carolingian period did not make up a majority of Jews and were in no way representative of the greater Jewish population. The Carolingian Empire was a primarily rural and forested place, with few towns in the west save for those built on old Roman town sites. ${ }^{18}$ Most Jews lived off the land as farmers, just as they had for most of their history. Some Jews, however, sought greater rewards for their generally higher level of education and literacy - as compared to most Christians-and elected to move into towns and take specialized, skilled jobs. Many local rulers realized the economic value of having a Jewish community and encouraged them to settle in their towns. The economic theory of path dependence indicates that shocks (stimuli) that influence changes in occupation will be permanent in the absence of 
countervailing shocks. In the Jewish case, the initial shock that moved them into urban, skilled occupations was the increased education and literacy resulting from the extra emphasis placed on personal Torah study by the rise of Rabbinic Judaism in the first two centuries CE. The local rulers encouraging Jewish immigration used their new subjects as merchants, craftsmen, tax collectors, court bankers, and later moneylenders. ${ }^{19}$ With incentives drawing them to the towns and no countershock to change their occupational path, it was practically inevitable that Jews would gradually urbanize, especially since many Jews were merchants and towns were important stations along both local and international trade routes.

Money was not yet a major feature of the European economy in the ninth and tenth centuries, so finance and moneylending had not yet become major occupations for Jews, particularly since no other occupations had yet been completely closed to them. However, a "Capitulary for the Jews" by Charlemagne in 814 indicates that some did lend money to a degree, as it bans them from taking "in pledge or for any debt any of the goods of the Church" or "to take any Christian in pledge." ${ }^{20}$ It was common practice at the time for a borrower to offer his freedom as collateral and, if he defaulted on a loan, to be taken into the custody of his creditor either as a hostage or a slave. This law of Charlemagne was likely a Church-inspired attempt to reduce Jewish control over Christians. Soon after, the Jewish right to own even non-Christian slaves was limited, removing them from their earlier pre-eminence in the slave trade and severely limiting their ability to participate in large-scale agriculture. The loss of this right alone had major ramifications and caused later longterm implications for the economic lives of France's Jews. Their decline had begun.

\section{Religious Attitudes toward Carolingian Jews}

Jews in the Carolingian Empire were not the social pariahs and financial specialists that they would later become in France, but neither were they universally tolerated. Hostility toward Jews at this time was anti-Judaism in the truest sense and appears to have emanated solely from the Church and its clerics. Unlike later irrational antiSemitism, which had a veneer of religion about it but deeper social and economic causes, the predominantly religious hostility of anti-Judaism grew out of the competition between the two religions. The Church and clerics of the time seem to have viewed Judaism as a genuine threat to Christianity, fearing and hating it as such. This is all the more understandable when one remembers that the majority of Christians in Carolingian Europe at the time were relatively new, and presumably reluctant, converts. Christianity had found dedicated adherents among the ruling class but had yet to become a true mass religion among the general population. Evidence of popular anti-Jewish feeling at this time is minimal, and any resentment seems to have come predominantly from the bishops. ${ }^{21}$ The social affinity between many Jews and Christians made the situation even more alarming for the Church. The clergy's serious concern indicates that the conversion of Christians to Judaism was not only a danger but also a reality which had already taken place, though it is impossible to know how many had converted. The Church's constant and vehement reiteration over several centuries of its strongly negative position on Christian-Jewish social interaction also indicates that its efforts were largely unsuccessful. ${ }^{22}$

Nowhere was the sense of alarm at the loss of Christians or potential Christians to Jewish proselytizers more evident than, once again, in the writings of Agobard of Lyon. Agobard made it clear in a letter to a few sympathetic courtiers of Louis the Pious around 823 that he was not satisfied that Jews had been rendered incapable of owning Christian slaves. He also pleaded on behalf of the potentially Christian 
pagan slaves (no mention is made of Jewish ones) serving in Jewish households. His cause for concern was that ownership by a Jew could be a major obstacle to a pagan being baptized into the Christian faith, thereby giving Judaism another advantage in the perceived competition with Christianity. Although pagans probably made up only a small segment of the Carolingian slave population, Agobard tries to give the impression of a captive and subjected people crying out for baptism because "they are pricked by [Carolingian culture] towards the love of Christ ... They flee to the Church, asking for baptism ..."23 Agobard indicates that pagan slaves desiring to be baptized legally needed the unlikely permission of their masters, and he cites the forced conversions of conquered peoples by Christian emperors as justification for doing so without permission. Of course, once a slave became a Christian, a Jew could no longer own him, and so laws were put in place to prevent unapproved baptisms. Although Agobard claims to support the compensation of Jews thus relieved of their legally owned human property, it apparently either was not put into practice or was not enough to satisfy the offended parties and prevent "human offense and the grievous wounding of our house [the church of Lyon].",24

Although the clerical hostility toward Jews during the anti-Judaic period was mostly based on the fear of Judaism's threat to Christianity as an organization, this was not enough to arouse the average early medieval layperson. They were more worried about the problems of day-to-day survival than the Church's recruitment and retention concerns. Instead, most of the public diatribes against Jews at this time appealed to emotional issues, with the age-old accusations of past deicide based on the trumped-up role of some Jews in Christ's crucifixion. ${ }^{25}$ Most effective, though, was the spread of rumors about continued secret Jewish hostility toward Christ and Christians. Preachers called Jews every manner of insult for allegedly being in league with Satan to attack Christ and his followers both spiritually and physically. ${ }^{26}$ Beliefs such as these were used as justifications for the restriction and subjugation of Jews throughout Europe. However, even where such arguments found sympathetic Christian ears, they were never translated into physical violence by the people. It must be remembered that the Church's official policy and the sermons of even its most venomous clerics in the early medieval period advocated only the segregation and legal, systemic oppression of Jews, but never physical violence against them. Nor was the banishment of Jews ever encouraged. The Church actively discouraged harming Jews because of Augustine of Hippo's fourth-century interpretation of the Cain and Abel story to mean that God had simultaneously cursed and protected the Jews for their "crime" against Christ in order for them to serve as exemplars of the consequences of perfidy. The continued misery of Jews was believed to bear witness to the truth of Christ's message and divinity as eternal punishment for their crimes against God and disbelief in the Gospels. ${ }^{27}$

Fortunately for the Jews of the time, however, it seems that the common people and their rulers in the Carolingian Empire were almost entirely unresponsive to the Church's and clerics' demands, thanks to the great divide between official Church teaching and what laypeople actually believed. Although the concept of separation of church and state did not exist at the time, secular rulers often allowed temporal rather than spiritual considerations to dictate policy. The common people were also more likely to be concerned with the exigencies of daily life than abstract theological accusations, especially when personal experience showed them that Jews were not evil demons but normal people. Part of the reason for tolerance of Jews by the Carolingian people was likely their relative newness to Christianity and the preservation in their religious attitudes of Germanic polytheistic tolerance, which expected every 
people to have their own gods and rituals. Their warlike culture may also have identified better with the harshness of the Old Testament and the similarities between Jews and Christians than they did with the New Testament with its message of pacifism and Christian-Jewish antagonism. ${ }^{28}$ Although Carolingian Jewish policy was inconsistent and varied across the reigns of many rulers, it remained relatively friendly, despite religious pressure from individuals such as Agobard. Since the people did not listen much to their preachers on this matter and formed no anti-Jewish ideas of their own, pogroms were unheard of at this time.

Charlemagne was the dominant figure in Carolingian history, but Louis the Pious and his other successors continued his pro-Jewish policies following his death. Louis even lifted some restrictions while resisting Church pressures to enhance them and actually enacted laws to protect Jews. Agobard of Lyon considered Louis' Jewish policies to be far too lenient and wrote many diatribes expressing his disapproval. This conflict culminated when the king humiliatingly rejected Agobard as he tried to raise his concerns at court after imperial officials denounced him for unlawfully baptizing a Jewish-owned slave in $822 .{ }^{29}$ Even when the Carolingian Empire began to break up, pro-Jewish policies continued in all regions. Clearly, anti-Judaism had not found a popular following in any sector of lay society. Even the clerics who passionately professed it were a minority. Interestingly, some preachers who promoted the official line and attacked Judaism and Jews as a group from the pulpit were often on friendly terms with individual Jews on a personal level, even entering into religious discussions with them. ${ }^{30}$

\section{Carolingian Dissolution and the "Rise" of the Capetians}

All things come to an end, and the Carolingian Empire was no exception when succession difficulties arose following the death of Louis the Pious in 840. In accordance with Frankish custom and the practice of his father Charlemagne, Louis had instructed that the empire was to be partitioned between his three sons, Lothar, Louis, and Charles. Although division of inheritance was an established Germanic principle, there was no way to ensure its implementation, so the three brothers fought and negotiated for dominion once their father had died. ${ }^{31}$ After three years of struggle, they signed the Treaty of Verdun in 843 and divided the empire into Francia Occidentalis, where Charles would reign, Francia Orientalis, where Louis would reign, and the Middle Kingdom, which Lothar would rule, keeping the imperial title. ${ }^{32}$ Francia Occidentalis in the west comprised most of the lands that make up modern France and will be the focus of this article from here on.

By the end of the tenth century, the descendants of Charles had suffered the same fate as the Merovingians two and a half centuries earlier and became inactive figurehead kings. They reigned, but did not rule. Instead, men who effectively held the post of "prime minister" conducted the work of government. Louis V was the last Carolingian king of France, and he reigned less than two years before dying, after which his chief administrator Hugh Capet, Duke of the Franks, took the throne in $987 .{ }^{33}$ In so doing, Hugh founded a new dynasty that would bear his name: the Capetians.

The kingdom Hugh inherited had declined along with its kings and did not constitute a cohesive political unit. The king could expect only nominal fealty from the lords of the land, and his influence diminished significantly the further he was from any particular area. The only real and direct power enjoyed by the Capetians was limited to a small territory surrounding Paris known as the Royal Domains. Essentially, the king ruled as a baron with a royal title. In fact, the first century of Cape- 
tian rule saw a decline in royal power throughout France, with a slow recovery beginning only around the end of Phillip I's reign (1060-1108). ${ }^{34}$ Royal domination of France was nominal, with local barons exercising real power while the Capetians put most of their effort into consolidating their authority in the Royal Domains and expanding it outwards. Most attention will be paid to the experiences of Jews in the Royal Domains when discussing the rise of political anti-Semitism, and a slightly wider focus will be used when examining the growth of popular anti-Semitism.

For the first century of Capetian rule there is little, if anything, that is possible to say about the role of Jews on the political scene, as they were not much involved in the dynastic transition. As mentioned above, the first king to make any significant gains for Capetian power was Phillip I in the early twelfth century, as he built up relationships between minor lords and the crown. ${ }^{35}$ Coinciding with the growth in Capetian power during the twelfth century was a change in the operation of the economy that began early in the eleventh century. The old bartering system was rapidly giving way to an increasingly commercial exchange economy. This explosion in the use and importance of money ${ }^{36}$ was to have grave implications for Jews and their relationship with the rest of society and the crown.

\section{Moneylending: A Jewish Niche and Its Consequences}

At the same time that the Carolingians gave way to the Capetians around the turn of the first millennium, changes began which caused many Jews to shift into what would become their stereotypical occupation-moneylending. A combination of push and pull factors caused this shift. Jews had effectively been forced out of large-scale agriculture when their rights to own Christian slaves were taken away and, although they were still able to own land, it was legally insecure and useless to them for anything beyond subsistence farming. The gradual barring of Jews from the developing merchant and craft guilds on the grounds of their prohibition from holding authority over Christians also forced them out of the higher skilled trades. ${ }^{37}$ At the same time, new financial opportunities arose due to the new monetary economy that required people to be able to borrow money on credit for growth and development. The Church, however, prohibited Christians from lending money to other Christians for the purpose of earning interest. This ban was based on an interpretation of a biblical passage, Deuteronomy 23:20: "You may charge a foreigner interest, but not a brother Israelite ..." Since the Christian Church saw itself as the new Israel, this moneylending ban was extended to all members of Christendom. Jews, however, were exempt from Christian restrictions.

The same Deuteronomic commandment, naturally, applied to Jews as well, and rabbinic authorities frowned upon lending at first, whether to a fellow Jew or a Christian. The great rabbi and commentator Rashi himself declared in the late eleventh century, "He who loans money at interest to a foreigner will be destroyed." 38 Less than a century later, necessity had softened rabbinic consensus: "no loans at interest must be made to the gentiles, if a livelihood can be earned in another manner," but "when a Jew may possess neither fields nor vines permitting him to live, the lending of money at interest to non-Jews is necessary and consequently authorized." 39 The potential to carve out a niche and gain a monopoly over a growing trade must have appealed deeply to many Jews, especially since their urbanization, historical experience as merchants, and higher standards of education suited them for it. However, attraction alone is not enough to explain the Jewish shift into moneylending. Most people will not opt to change occupation simply because they can. Instead, it was the external influence of occupational restrictions 
that gradually forced Jews off their farms and out of their workshops. The principle that Jews must not control Christians was far more powerful in pushing them out of agriculture and the guilds than the rise of a capital economy, and the Church's ban on Christians charging interest to each other were in drawing them to the money table.

The majority of Jews still scratched out livings in low-level occupations, but the minority who did move into moneylending was a highly visible one. These Jewish financiers inadvertently formed the seed of the stereotype of the "money-loving Jew," which has found incredible longevity and fame. Medieval Christians found it especially easy to associate all Jews with moneylending since, relative to the Christian majority, a greater proportion of the Jewish community were moneylenders even when Christians made up the majority of lenders overall. This proportion must have appeared even larger, since virtually all moneylenders lived in towns and so comprised a sizeable percentage of urban Jews when their poorer co-religionists remained in the countryside. In this way the Jewish economic role in medieval France was disproportionate to Jewish numbers both in reality and even more so in the Christian imagination. This powerful association between Jews and moneylending remained pre-eminent even when Christians (particularly Italians) disobeyed the usury ban and began to make up a majority of the financial market overall. ${ }^{40}$

In spite of the unrealistic representation of Jews as chronic moneylenders and the extremely negative stereotype that later grew out of it, Jewish lenders in the late eleventh and twelfth centuries actually provided an important and appreciated service in two ways. First, they helped to grow an increasingly money-based economy that Church policy otherwise hindered. ${ }^{41}$ Second, Jewish lenders contributed to the survival of many poor people who needed borrowed money in order to meet the necessities of day-to-day life. ${ }^{42}$ It is perhaps only natural however, considering human nature, that many Christians came to resent the Jews for their new role in spite of its benefits, whether because of jealousy, suspicion, or personal insecurities. The prejudice was all the more potent since Jews were already marked out as different from the rest of society. The Jewish writer Joseph Kimhi of Narbonne wrote in the mid-twelfth century of the double standard applied to Jewish and Christian lenders, despite the latter's higher interest rates and less-reputable business practices. ${ }^{43}$ Jewish reactions to Christian hostility definitely indicate that envy was one likely motive for attacks on their communities. Jewish communities (kehillot) in northern France enacted laws placing self-imposed restrictions on the behavior of their members. Limits were set on the kinds of clothing that could be worn, the type and amount of jewelry, and the size and nature of banquets given. The leaders of the kehillot acknowledged that ostentatious shows of wealth such as these by a few Jews would arouse the jealousy and anger of Christian neighbors against the entire community if left unchecked. ${ }^{44}$

The fact that only a minority of Jews were moneylenders and that fewer still had any great wealth did not seem to allay the Christian hostility against their entire community. The actions of the kehillot confirm that the economic status of a few Jews engendered the hostility of the Christian majority against all their coreligionists and initiated the formation of an enduring stereotype. Human beings have a tendency to form mental schemas, assuming that all members of a particular group share certain characteristics and may even be all the same. People usually draw these conclusions from direct observations of only a few members of the group in question or even from mere rumor and hearsay. These conclusions are then generalized to the entire group. In sociological terms, this phenomenon is called the out- 
group homogeneity effect and has been used to establish "Otherness" and dehumanize victim groups many times throughout history. ${ }^{45}$ Furthermore, humans are prone to the accentuation effect, which establishes a confirmation bias that remembers negative characteristics of an "Other" individual or group while ignoring positive qualities or characteristics that contradict presuppositions, even if those positive qualities are more numerous. ${ }^{46}$ In medieval France, these two factors meant that all Jews quickly came to be associated with the financial activities of a few of their highly visible co-religionists.

Religious leaders of the time quickly realized that the new Jewish "offence" to Christendom could be very useful. They soon changed their angle of attack from the old, purely religious rhetoric to a new combined religious, economic, and social one that the laity was much more prepared to accept. Preachers started portraying moneylending as a weapon in the Jewish arsenal being used to attack and undermine Christendom either as part of a Jewish fifth column in alliance with the Muslims, or in the service of the Devil himself to prepare the way for the Antichrist. ${ }^{47}$ Once the laity accepted this rhetoric, it was an easy progression to forming and believing other erroneous accusations against Jews. Political leaders, while finding Jews economically useful and protecting them for a time, also began to see the propaganda value of their new status and did not hesitate to exploit it.

\section{Transition: The Blois Massacre and the First Expulsion}

When Jews began to move into moneylending in sufficiently large numbers during the twelfth century, Christians began to see it as a "Jewish" occupation. At the same time, another change took place in European society. The old clerical, religious anti-Judaism that the laypeople and rulers of Europe had ignored for so long began to give way to a popular, irrational hostility which can be called true anti-Semitism for the first time. This change happened because the growing hostility and stereotypes surrounding Jewish moneylending psychologically prepared common Christians to accept rumors about the other harmful activities that Jews supposedly carried out in secret. In the minds of many Christians, Jews became financially parasitic "Others" who committed untold horrors in private. They had long been painted by clerics like Adhemar of Chabannes as the Devil's agents sent to earth to attack Christ and Christians. Around the turn of the millennium, the preacher Ralph Glaber articulated "the wickedness of the Jews" which he alleged had led to the destruction of the Church of the Holy Sepulchre in Jerusalem ${ }^{48}$ by their supposedly devilish Muslim allies under the Caliph al-Hakim. Common Christians never seem to have believed such accusations, of which they could see no evidence and which had such distant results. Now that the new "evil" of Jewish moneylending was present in everyday life for all to see, when Christians heard it denounced in church as an attack on their society, the association was easier to make.

Once the idea of the Jewish menace had been established and internalized, it was not much of a leap for poorly understood Jewish rituals and customs to also be accepted as part of an anti-Christian campaign. The average medieval Christian peasant had only the barest understanding of his/her own religion, let alone the alien practices of Jews that took place behind closed doors. Furthermore, the belief that Jewish religious and economic activities were actually spiritual attacks carried out in the name of the Devil naturally resulted in the acceptance of further accusations that Jews did actual physical harm to Christians in the course of their evil spiritual services. Christians began to accept such rumors, if for no other reason than that they had no concrete reason to disbelieve them. ${ }^{49}$ Unexplained deaths, for 
which the common people demanded answers and justice, could then be blamed on the Jews by troublemakers. Such accusers usually had the tacit (and sometimes enthusiastic) approval of the authorities, who knew the placement of guilt would be accepted by the people. As a marginalized, defenseless, and demonized minority, the Jews made very plausible scapegoats.

Violence, often on a large-though never truly exterminatory-scale, was the natural outcome of accusations against a dehumanized and feared group such as medieval French Jews, especially when there was not enough evidence for a legitimate trial and mob justice took over. Local authorities often approved of, and sometimes encouraged, the lynching of Jews in this way whether because of apathy, genuine hostility, or greed for confiscated Jewish wealth. This was certainly the case at the first French ritual murder accusation: the "trial" and burning of Jews at Blois in May 1171. Ephraim ben Jacob of Bonn, a German-Jewish Talmudist and poet, gave an account of the incident at Blois in his work "A Book of Historical Records." No reason is known for the ritual murder accusation to have happened at that place and time, but it may have been an echo of the similar William of Norwich scandal in England in 1144. Ephraim recounts that about forty Jews lived in Blois at the time that one of them was accused of disposing of a Christian corpse. The man was watering his horse at the river when a soldier doing the same with his master's horse claimed that the animal spooked at the sight of the Jew. Somehow, the soldier turned this episode into a story that he immediately told his master about a Jew whom he saw "throw a little Christian child, whom the Jews have killed, into the water." 50 Remembering his hatred of "a certain Jewess influential in the city," the master saw a chance for vengeance and immediately reported the "crime" to the ruler of Blois, Count Theobald V. ${ }^{51}$ Theobald believed the story and imprisoned all the Jews of Blois as a result. He had no evidence against them-not even a bodybut saw an opportunity to profit by ransoming the entire Jewish community to Jews in the neighboring cities. Extremely outdated and misapplied methods of trial by ordeal were used to prove the "truth" of the accusation against the Jews, while the arrival of a hateful priest swayed Theobald's mind from mercy and ransom to punishment. On 26 May, more than thirty of the forty Jews of Blois were burned alive. ${ }^{52}$ Their torment was the first episode of its kind in continental Europe and set a dangerous precedent. Both Theobald and his subjects enthusiastically accepted the ritual murder accusation and sought a gruesome vengeance at the urging of a simple priest. The whole episode lacked even the veneer of a legitimate legal case or sincere religious justification. Something had changed. These Christians hated Jews not as human members of an alien religion, but irrationally, as something they objectively were not: evil and secret murderers of the innocent. Anti-Semitism had arrived, and it was both popular and political.

It must be noted that ritual murder pogroms differed greatly from the massacres of Jews that took place during the First Crusade. The crusaders who slaughtered Jews in the Rhineland and at Rouen in France (the only place where the French king and bishops were unable to protect Jews) were not the aristocratic and officially state-sponsored soldiers sent to recapture the Holy Land. The people who so viciously attacked Jews during the crusade were almost universally commoners. They were non-professional soldiers and hangers-on, urged to unrestrained violence by grass-roots leaders on religious grounds. ${ }^{53}$ Moreover, these renegade crusaders attacked Jews in a time of heightened religious sentiment when they had been gathered for the purpose of killing non-Christians to begin with. To these low-level crusaders an infidel was an infidel, and the distinction between Jew and Muslim 
was a moot point since all were the enemies of Christ and thus deserved to die. Their behavior, however, was discouraged at the time by most rulers and by members of the Church hierarchy. ${ }^{54}$

Much had changed seventy years after the First Crusade. The killings at Blois did not occur in an atmosphere of increased religious feeling by a community facing an external threat of any kind, but rather in a safe and peaceful town. Although, as Ephraim of Bonn notes, the final decision to burn the Jews of Blois came at the instigation of a priest, there was no religious motive in the initial acceptance of the accusation or decision to persecute them. Also, it was a political figure, Count Theobald, who provided the main impetus to attack the Jews, quite unlike his Crusader counterparts who discouraged such behavior. Lastly, the common men who carried out Theobald's sentence on the Jews massacred their neighbors, who clearly posed no threat to the community.

Interestingly, Louis VII was the king of France and Count Theobald's brother-inlaw at the time of the Blois massacre. Louis strongly condemned the accusations against the Jews of Blois and renewed assurances of his protection to the Jewish community in his domains ${ }^{55}$ (Blois being just outside the king's sphere of direct influence). Clearly, anti-Semitism had not yet become institutionalized at the highest levels of society, although Louis' words were probably motivated more by economic considerations than humanitarianism. Jews had become mere pawns for rulers due to their new economic role. The developing political anti-Semitism was more a phenomenon of abuse of power and realpolitik than of hatred, fear, or religious belief. Unlike the previous centuries when Jews were free and equal subjects who had a special partnership with kings, by the late twelfth century their survival was based entirely on their economic and political usefulness. The Jews were yet another point of contention, along with minting rights and authority over serfs, over which the Capetian monarchs battled their vassals during the long struggle to unite and dominate France. They were pieces of property around whom kings built very strong legal claims for the rights of the crown. ${ }^{56}$

The Jews were an important source of money for the king even more than they were a source of legal leverage. Rulers always need money, especially those who are trying to build up their power base. The majority of loans that medieval Jews made were to such rulers, and the business relationship generally went smoothly. The Jews had several methods to ensure that they were repaid on time. Pawnbroking secured loans when enough physical collateral was available, as did royal grants of tax rights to the Jews, and Jewish threats of collective boycott should one of them be cheated. ${ }^{57}$ Theoretically, no king would default on a loan if it meant that he would never get another one. Sometimes, though, rulers ignored the consequences and sought profit from the Jews by attacking rather than protecting them. The collective confiscation of property or repudiation of loans from all Jews could bring in a large one-time gain, while simultaneously removing the threat of boycott and neutralizing the Jewish community's source of leverage. ${ }^{58}$ Kings found this option very attractive when another non-Jewish source of credit was available.

The young king Philip II Augustus was intent on expanding royal power as much as possible when he came to the French throne in 1179. Only fifteen years old, Philip was nonetheless a shrewd ruler and knew right away that he needed vast quantities of money in order to fight the feudal barons for power and win. ${ }^{59}$ The best medieval source of information on Philip and France at this time comes from the book "Gesta Philippi Augusti" by the monk Rigord of St. Denis. Apparently, Philip immediately recognized that Jews were useful to his plans and he set to work persecuting them 
within months of ascending the throne. Four months into his reign, Philip imprisoned every single Jew in the Royal Domains. He released them in 1180, only after receiving a large ransom. In 1181 Philip annulled all Jewish loans that had been made to Christians and retained $20 \%$ for the crown. Finally, in 1182, Philip issued the last blow to the Jews by confiscating their homes, buildings, and land, banishing them from the Royal Domains effective the feast of St. John the Baptist on 24 June. $^{60}$

Rigord justifies Philip's expulsion of the Jews of his lands in religious terms. He claims that Philip knew full well how "the Jews who dwelt in Paris were wont every year on Easter day... to go down secretly into underground vaults and kill a Christian as a sort of sacrifice in contempt of the Christian religion." ${ }^{61}$ Apparently, the final offence came when the Jews "used so vilely" some church vessels given to them as security on a loan. ${ }^{62}$ Whether or not Philip really believed such accusations will never be known, but he likely did not care about the truth, instead only wanting to use them as effective propaganda in his attacks. The confiscation and expulsion of 1182 did, however, serve several practical worldly purposes that Philip fully calculated and believed in. First, the financial revenues from taking over Jewish property and the claims on their debts hugely enriched the crown. Under former circumstances, Philip would have ruined any chances at future loans by thus impoverishing and alienating the Jewish community. However, Italian moneylenders had established a growing presence in France and were ready to fill the gap. A ruler in such a situation did not have to fear boycott, but did stand to make a substantial one-time gain while enjoying continued credit from a new source. ${ }^{63}$ Second, the expulsion itself ensured the support of the French Church and the goodwill of the clergy. Official papal policy rejected the persecution and expulsion of Jews but, as has been seen, many lower-level clerics ignored this and would have welcomed the Jews' expulsion. Finally, even the most undemocratic tyrant still cares about public opinion to some degree and wants the support of his subjects. It was important for Philip to establish this popularity early in his reign, and the expulsion of what had become a feared and hated minority was an excellent way to do so. Philip's religious pretences for the expulsion would have made this public relations coup all the more effective because of his appearance to be cleansing Christian France of the Devil's Jewish servants.

The expulsion of 1182 was small in scope due to the limited geographical area to which it applied. It was also a temporary measure, for the king would allow Jews back into his lands by the end of the century. Philip Augustus' expulsion of the Jews, however, had significance beyond its scale. It was the first such expulsion anywhere in Europe, and signaled that the Jews had fully fallen from being protected and favored royal subjects to political pawns at the mercy of their rulers. Jews could now be used as tools to raise money, settle political disputes, or gain the support of the masses. The events of 1182 had set a dangerous and much-followed precedent for the rest of Europe, particularly the western half, which was entirely free of Jews three centuries later. Although the Jews were eventually allowed back into the French Royal Domains, they suffered repeated banishments until their last remnants were forced out in 1394. English Jews were expelled in 1290 due to complications related to moneylending, and those in Germany, Spain, and parts of Italy faced much harassment and violence before their own final expulsions in the fifteenth and early sixteenth centuries. ${ }^{64}$ From a modern point of view, the most significant aspect of the 1182 expulsion is clearly that Philip Augustus had ushered in the age of political anti-Semitism at the highest levels of government and society. 


\section{Conclusion}

Over the four centuries from the rise of the Carolingians to their first expulsion from France, the Jews under royal control occupied a steadily worsening position in society. By the end of that period they had lost their original acceptance and privileged place. Although intolerance of Jews was nothing new in Christendom, it definitely grew and morphed as the earlier clerical anti-Judaism gave way to an irrational popular and political anti-Semitism. The change in employment opportunities forced many Jews into taking on an economic role that was the main factor leading to their downfall. Without the restrictions which led to that change of occupation, and which consequently influenced popular attitudes toward Jews and religious accusations against them, the Jews of France would likely have continued living as a protected minority condemned from the pulpit but accepted by their neighbors. The growing hatred of Jews as a group was in no way inspired by their real behavior. Rather, Jewish moneylending simply provided a catalyst for the spread of false preconceived and generalized notions about Jews. ${ }^{65}$ Without the adoption of moneylending as a major Jewish occupation, the common people would never have seen any "evidence" of Jews as a dangerous minority feeding off of Christian society and plotting its destruction. Instead, seeing Jewish "predators" financially "attacking" Christians through usury planted the idea in the average layperson's mind that perhaps they were dangerous after all. The way was paved for anti-Semitism: if Jews did such terrible things publicly, many Christians likely reasoned, just imagine what they did in secret. Suddenly, all of the long-proposed but unpopular religious propaganda portraying Jews as demonic enemies seemed a little more realistic. Eventually ready to believe anything, laypeople accepted these ideas and a mob mentality carried them away into unthinking fear and hatred. The most baseless of accusations suddenly became legitimate grounds for the bloodiest of massacres.

State protection that normally would have stopped anti-Jewish violence not only disappeared but also turned into tacit approval and then active persecution as rulers realized the value of exploiting Jews. Whether as a means to indirectly tax the people, a source of wealth for confiscation, scapegoats for crimes and social problems, or tools to raise popular and clerical support by periodic "religious" persecutions, few things were more useful to a ruler than a helpless Jewish community. The period of transition from anti-Judaism started in 1171 with the Blois massacre and concluded with the expulsion of 1182. The former signaled the arrival of popular anti-Semitism and the latter the arrival of its political counterpart. Both set dangerous precedents that were repeated in France and all over Europe for centuries to come. Most importantly, these events marked a sinister transition in the treatment of Jews by all levels of society, often independently of religious cause. Anti-Semitism had arisen and established Jews as dehumanized enemies of the common good, though the phenomenon would continue to evolve for centuries.

Ultimately, when viewed in a much broader historical context, the events beginning in the twelfth century clearly helped to create the atmosphere that enabled another major reinvention of Jew-hatred with the Nazi racialization of anti-Semitism in the early twentieth century. The Nazis exploited many ancient myths about Jews, including the blood libel, demonological imagery, and especially the portrayal of Jews as parasitic internal enemies preying upon their non-Jewish neighbors, largely through economic means. ${ }^{66}$ The vast span of history and the lack of medieval genocidal intent preclude a direct causal link between the rise of medieval anti-Semitism and the Holocaust. However, the fires of Blois were, without a doubt, important first 
steps on the long road to the ultimate catastrophe of European Jewry almost eight centuries later.

\section{Notes}

1. Robert Chazan, Medieval Stereotypes and Modern Antisemitism (Berkeley: University of California Press, 1997), 126.

2. Gavin I. Langmuir, History, Religion, and Antisemitism (Berkeley: University of California Press, 1990), 275.

3. Ibid., 128.

4. The terms semi-rational and irrational are used here to describe the different sources and natures of anti-Judaism and anti-Semitism. Anti-Judaism is considered to be semirational because its proponents appeared to engage in logical thought processes regarding the actual differences between Jewish and Christian beliefs and practices. They regarded Jews as equally human to themselves and believed that their wayward souls could be saved through conversion to Christianity. However, the prejudices which arose from these thought processes were no more valid due to their origin and are therefore not fully rational from an objective point of view. Anti-Semitism, on the other hand, is considered to be completely irrational in nature because it is based on emotional reactions to erroneous beliefs about the nature and often fictitious practices of Jews, who are themselves regarded as being either subhuman or supernatural beings. Anti-Semites viewed Jews as being evil not because of their actual actions or beliefs, but because of what they were believed to be.

5. Bernard S. Bachrach, Early Medieval Jewish Policy in Western Europe (Minneapolis: University of Minnesota Press, 1977), 65.

6. Pierre Riche, The Carolingians: A Family Who Forged Europe, trans. Michael Idomir Allen (Philadelphia: University of Pennsylvania Press, 1983), 52.

7. Ibid., 59 .

8. Ibid., 68.

9. The "personality of the law" is a term referring to the early medieval legal principle that individuals were subject to the laws of their ethnic group or homeland at all times, even when traveling abroad or living as a minority in another culture. For example, a Frank accused of a crime while traveling in Visigothic lands would be tried for the offence under Frankish law, rather than Visigothic law.

10. Bachrach, Early Medieval Jewish Policy, 66.

11. Agobard of Lyon, "On the Insolence of the Jews to Louis the Pious (826/827)," in The Internet Medieval Sourcebook, http://www.fordham.edu/halsall/source/agobard-insolence. html (accessed 18 October 2009).

12. Bachrach, Early Medieval Jewish Policy, 97.

13. Ibid., 35-36.

14. Agobard of Lyon, "On the Insolence of the Jews to Louis the Pious."

15. AdriaanVerhulst, The Carolingian Economy (Cambridge: Cambridge University Press, 2002), 130-31.

16. Ibid., 105 .

17. Ibid., 88, 131.

18. Ibid., 21.

19. Maristella Botticini and Zvi Eckstein, "Path Dependence and Occupations," in The New Palgrave Dictionary of Economics Online, ed. Lawrence Blume and Steven N. Durlauf (Houndmills, UK: Palgrave Macmillan, 2008), http://www.dictionaryofeconomics.com/ article?id=pde2008_P000318 (accessed 21 January 2010).

20. Charlemagne, "Capitulary for the Jews, 814," in The Internet Medieval Sourcebook, http://www.fordham.edu/halsall/source/814capitul-jews.html (accessed 18 October 2009).

21. Walter Laqueur, The Changing Face of Anti-Semitism: From Ancient Times to the Present Day (Oxford: Oxford University Press, 2006), 51. 
22. Esther Benbassa, The Jews of France: A History from Antiquity to the Present, trans. M.B. DeBevoise (Princeton, NJ: Princeton University Press, 1999), 6-7.

23. Agobard of Lyon, "On the Baptism of Slaves Belonging to Jews (to Adalard, Wala, and Helisachar)," in The Internet Medieval Sourcebook http://www.fordham.edu/halsall/ source/agobard-baptism.html (accessed 18 October 2009).

24. Ibid.

25. Steven T. Katz, The Holocaust in Historical Context, vol. 1, The Holocaust and Mass Death before the Modern Age (New York: Oxford University Press, 1994), 241-46.

26. Ibid., 259-61.

27. Ibid., 260-64.

28. Gavin I. Langmuir, Toward a Definition of Antisemitism (Berkeley: University of California Press, 1990), 78.

29. Bachrach, Early Medieval Jewish Policy in Western Europe, 99-100.

30. Michael Frassetto, "Heretics and Jews in the Writings of Ademar of Chabannes and the Origins of Medieval Antisemitism," Church History 71 (2002): 1-15.

31. Riche, The Carolingians, 160.

32. Ibid., 165-66.

33. Elizabeth M. Hallam and Judith Everard, Capetian France: 987-1328, 2nd ed. (Harlow, UK: Pearson Education, 2001), 25.

34. Ibid., 119.

35. Ibid., 119-21.

36. Benbassa, The Jews of France, 14.

37. Langmuir, Toward a Definition of Antisemitism, 305.

38. Leon Poliakov, The History of Antisemitism, vol. 1, From the Time of Christ to the Court Jews, trans. Richard Howard (New York: Vanguard Press, 1965), 75.

39. Ibid.

40. Joseph Shatzmiller, Shylock Reconsidered: Jews, Moneylending, and Medieval Society (Berkeley: University of California Press, 1990), 93.

41. Yoram Barzel, "Confiscation by the Ruler: The Rise and Fall of Jewish Lending in the Middle Ages," Journal of Law and Economics 35 (1992): 1-13.

42. Shatzmiller, Shylock Reconsidered, 80-82.

43. Ibid., 94.

44. Benbassa, The Jews of France, 30-31.

45. James Waller, Becoming Evil: How Ordinary People Commit Genocide and Mass Killing (New York: Oxford University Press, 2002), 240.

46. Ibid.

47. Christopher Ocker, "Ritual Murder and the Subjectivity of Christ: A Choice in Medieval Christianity," Harvard Theological Review 91 (1998): 153-92.

48. Ralph Glaber, "On the First Millennium," in The Internet Medieval Sourcebook, http:// www.fordham.edu/halsall/source/glaber-1000.html (accessed 18 October 2009).

49. Langmuir, Toward a Definition of Antisemitism, 309.

50. Ephraim ben Jacob of Bonn, "The Ritual Murder Accusation at Blois, May, 1171," from A Book of Historical Records (ca. late 12th c.), in The Internet Medieval Sourcebook, http:// www.fordham.edu/halsall/source/1171blois.html (accessed 18 October 2009).

51. Ibid.

52. Ibid.

53. Katz, The Holocaust and Mass Death before the Modern Age, 330.

54. Ibid., 323-24.

55. Ibid., 356.

56. William Chester Jordan, "Jews, Regalian Rights, and the Constitution in Medieval France," AJS Review 23 (1998): 1-16.

57. John M. Veitch, "Repudiations and Confiscations by the Medieval State," Journal of Economic History 46 (March 1986): 31-36.

58. Ibid. 
59. Jacob R. Marcus, The Jew in the Medieval World: A Source Book, 315-1791 (New York: Meridian Books, 1960), 24.

60. Rigord of St. Denis, "Gesta Phillippi Augusti," excerpted in Jacob R. Marcus, The Jew in the Medieval World: A Source Book, 315-1791 (New York: Meridian Books., 1960), 24-27.

61. Ibid.

62. Ibid.

63. John M. Veitch, "Repudiations and Confiscations," 31-36.

64. Anna Foa, The Jews of Europe after the Black Death (Berkeley: University of California Press, 2000), 9-13.

65. Katz, The Holocaust and Mass Death before the Modern Age, 397.

66. Marvin Perry and Frederick M. Schweitzer, Anti-Semitism: Myth and Hate from Antiquity to the Present (New York: Palgrave Macmillan, 2002), 1-7. 